\title{
Spatial patterns in the condition index of the wild Pacific oyster Crassostrea gigas in a macrotidal coastal ecosystem: Influence of tidal processes and beyond
}

\author{
Gasmi Sonia ${ }^{1,{ }^{*}}$, Bernard Ismaël ${ }^{2}$, Pouvreau Stéphane ${ }^{3}$, Maurer Danièle ${ }^{4}$, Schaal Gauthier ${ }^{5}$, \\ Ganthy Florian ${ }^{4}$, Cominassi Louise ${ }^{1}$, Allain Gwenhael ${ }^{6}$, Sautour Benoit ${ }^{1}$, David Valérie ${ }^{1}$
}

${ }^{1}$ Université de Bordeaux, Environnements et Paléoenvironnements Océaniques et Continentaux (EPOC), UMR 5805, Station marine d'Arcachon, 2 rue du professeur Jolyet, 33120 Arcachon, France

${ }^{2}$ Comité Régional Conchylicole Arcachon Aquitaine (CRCAA), 15 rue de la Barbotière, 33470 GujanMestras, France

${ }^{3}$ Ifremer, Laboratoire des Sciences de L'Environnement Marin (LEMAR), UMR 6539, 11 Presqu'île du

vivier, 29840 Argenton, Landunvez, France

${ }^{4}$ Ifremer, Laboratoire Environnement Ressources d'Arcachon (PDG-ODE-LITTORAL-LERAR), Station d'Arcachon, Quai du Cdt Silhouette, 33120 Arcachon, France

${ }^{5}$ Université de Bretagne Occidentale, Laboratoire des Sciences de L'Environnement Marin (LEMAR), UMR 6539, Rue Dumont D'urville, 29280 Plouzané, France

${ }^{6}$ Armeria, 31B rue de la Concorde, 56670 Riantec, France

*Corresponding author : Sonia Gasmi, email address : s.gasmi@epoc.u-bordeaux1.fr

ismael.bernard@eureka-model.com ; stephane.pouvreau@ifremer.fr ; daniele.Maurer@ifremer.fr ; gauthier.schaal@univ-brest.fr ; florian.ganthy@ifremer.fr ; armeria@orange.fr ;

b.sautour@epoc.u-bordeaux1.fr ; v.david@epoc.u-bordeaux1.fr

\begin{abstract}
:
In macrotidal coastal ecosystems, spatial heterogeneity of the water column properties is induced by both oceanic and continental influences. Hydrodynamic processes generate a land-sea gradient of environmental conditions, affecting the biological performances of sedentary organisms. The aim of the present study is to establish an extensive spatial assessment in the reproductive investment of the wild Pacific oyster Crassostrea gigas in Arcachon Bay. This is done by looking for a relationship between the Lawrence and Scott condition index $\left(\mathrm{LS}_{\mathrm{Cl}}\right)$ and two tidal processes: the immersion level $\left(\mathrm{I}_{\mathrm{L}}\right)$ and the local oceanic flushing time (LoFt). The $\mathrm{LS}_{\mathrm{Cl}}$ of $C$. gigas was assessed, just before gamete release, at 68 sampling stations in Arcachon Bay. Oyster performance was overall low and spatially variable. Significant differences in the $L_{\mathrm{Cl}}$ were detected between the outer and inner bay. Oyster reefs located toward the mouth of the bay exhibited high LS $_{\mathrm{Cl}}$ (between 9 and 11), while oyster reefs located in inner bay, especially in south-eastern part around the Eyre River, had low LS $\mathrm{CI}_{\mathrm{CI}}$ (below 6). Linear modelling allowed to highlight significant effects of both tidal processes $\mathrm{I}_{\mathrm{L}}$ and LoFt on the obtained $\mathrm{LS}_{\mathrm{Cl}}$ gradient. $I_{L}$, LoFt explained $33 \%$ of the spatial variability observed on $L_{C S}\left(I_{L}=3 \%\right.$; LoFt $=17 \%$; LoFt $\left.+I_{L}: 13 \%\right)$, $6 \%$ were attributed to the intra-station variation (ISv). Thus, high $\mathrm{I}_{\mathrm{L}}$ and rapid LoFt favor a better development of somatic-gonadal volume, probably because of longer feeding time and higher supply of
\end{abstract}


food from the ocean by tide flows. Disentangling the effects of $I_{L}$ and LoFt on $L S_{C l}$ allowed to describe the spatial pattern in $61 \%$ of variability not explained by both tidal factors. A residual gradient directed southeast-northwest highlighted that others factors, independent from $\mathrm{I}_{\mathrm{L}}$ and LoFt seems to hamper inner bay oyster reproductive performance. Consequently, investigating on the ecological functioning (Eyre influences), trophic potential and anthropogenic pressures of this zone seem crucial on the understanding of $C$. gigas reproductive pattern in Arcachon Bay.

\section{Highlights}

- Highest condition index $\left(\mathrm{LS}_{\mathrm{Cl}}\right)$ of Crassostrea gigas in ocean-influenced areas than in river-influenced areas Immersion level $\left(\mathrm{I}_{\mathrm{L}}\right)$ and local oceanic flushing time (LoFt) explained $33 \%$ of $\mathrm{LS}_{\mathrm{Cl}}$ spatial variability Long food access time and rapid water renewal from the ocean enhance $C$. gigas gonadal development

Keywords : Reproductive investment, Crassostrea gigas, Macrotidal lagoon, Immersion level, Oceanic flushing, Environmental variability

\section{Abbreviations}

- $\quad \mathrm{LS}_{\mathrm{Cl}}$, Lawrence and Scott condition index;

- IL, Immersion Level;

- LoFt, Local oceanic flushing time;

- ISv, Intra-station variation 


\section{Introduction}

In marine aquaculture areas, natural spat collection of the Pacific oyster Crassostrea gigas depends on the reproductive output of both farmed and wild stocks. However, although natural beds can significantly contribute to the overall gamete release, few studies have assessed their reproductive capacities (Cardoso et al., 2007; Dutertre et al., 2010; Lango-Reynoso et al., 1999). Monitoring of natural populations has mostly been limited to the evaluation of livestock biomass and distribution (Cognie et al., 2006; Martin et al., 2005; Scourzic et al., 2012; Soletchnik et al., 2012). In contrast, more research on oyster reproductive effort focused on farmed stocks (Berthelin et al., 2000; Dutertre et al., 2009; Enríquez-Díaz et al., 2009; Lango-Reynoso et al., 2000). Recently in Arcachon Bay, the high inter-annual fluctuations in spat collection raised some question on the reproductive output of wild oyster beds (Bernard, 2011). It seems that, in addition to the monitoring of farmed stock, it is crucial to focus on the reproductive output of wild populations. This is of special importance for the assessment of aquaculture health and in the development of spat production predictive models. In particular for coastal ecosystems where spat collection constitutes an important economic activity, such as Arcachon Bay.

Reproductive performance of C. gigas is primarily conditioned by local environment (Alunno-Bruscia et al., 2011; Bourlès et al., 2009). Both temperature and food supply constitute the main drivers of $C$. gigas gametogenetic cycle (Chávez-Villalba et al., 2002a, 2002b; Dridi et al., 2007; Dutertre et al., 2010; Enríquez-Díaz et al., 2009; Fabioux et al., 2005; Kang et al., 2000). Temperature is triggering gametogenesis, gonadal development dynamics and egg maturation, while food quantity and composition enhance fertility and gametes quality (Enríquez-Díaz et al., 2009; Fabioux et al., 2005). In response to local and regional differences in these main factors, $C$. gigas reproductive output exhibits significant geographical and spatial variability (Bernard et al., 2011; Cardoso et al., 2007; Pouvreau et al., 2016; Royer et al., 2007).

In macrotidal coastal ecosystems, tides and freshwater inflow from adjacent rivers are responsible for most of food supply variability (Cloern et al., 1989; Monbet, 1992; Powell et al., 1989; Trigueros and Orive, 2000). Consequently, the biological condition and feeding of C. gigas is known to be spatially variable within their ecosystem habitat (Leal et al., 2008; Marchais et al., 2013; Riera and Richard, 1996; Royer et al., 2007). Differences can arise between suspension-feeders living at different tidal levels on the shore: the time of aerial exposure increases 
with elevation, reduces feeding time and increases the intensity of abiotic factor effects for high-shore communities (Gillmor, 1982; Goulletquer et al., 1987). On the other hand, tidal forcing (i.e. current velocity, tide amplitude, flushing time) induces large variability of the quantity and quality of food available to suspension-feeders (Newell, 2004; Prins et al., 1997). Food supply is ensured by water renewal, material resuspension, and allochtonous organic matter inputs from the nearshore zone (Grant, 1996; Roegner and Shanks, 2001; Roegner, 1998), in addition to local primary production, which can be enhanced by nutrient inputs from the drainage basin and adjacent rivers (Mallin et al., 1993).

This study was carried out in Arcachon Bay, a semi-enclosed bay of French Atlantic coast (southwest of France), characterized by a macrotidal regime. The bay is marked by strong spatial and temporal heterogeneity of the water column (Glé et al., 2008; Plus et al., 2009). The water renewal is mostly ensured by oceanic flushing from the Bay of Biscay and, to a lesser extent, by freshwater inflows from adjacent rivers (Castel et al., 1996; Plus et al., 2009) (see material and methods; Fig. 1). Arcachon Bay is not concerned by eutrophication events since nutrient inputs are moderate and tidal water exchange with the ocean sufficient (De Wit et al., 2001; Plus et al., 2009). Depending on the seasonal balance between tidal flushing and freshwater inflows, temporal and spatial hydrobiological changes in the land-sea gradient can occur, affecting the dynamics of the autotrophic compartment (Glé et al., 2008) and potentially the availability of trophic resources for C. gigas (Grangeré et al., 2012).

Arcachon Bay historically provides an important amount of spat for oyster farming in France. High annual fluctuation in spat production of C. gigas in Arcachon Bay has been reported since 1998 (Auby et al., 2014). These variations occur in parallel with two trends in Arcachon Bay: (i) decreasing abundance of the first larval stage of $C$. gigas, and (ii) delay spawning period (see for instance Pouvreau et al., 2016). Since reproductive effort seems to be involved in this variability of spat collection, the main objective of this study is to describe the spatial pattern in the condition index of wild $C$. gigas stock at the bay scale, in relation with the tidal processes. Firstly, through an extensive spatial assessment of $C$. gigas somatic-gonadal index just before spawning, and secondly by the investigation of the role of immersion level $\left(\mathrm{I}_{\mathrm{L}}\right)$ and the local oceanic flushing time (LoFt), that may control the reproductive pattern in Arcachon Bay. 


\section{Material and Methods}

\subsection{Study site}

Arcachon Bay $\left(44^{\circ} 40^{\prime} \mathrm{N}, 1^{\circ} 10^{\prime} \mathrm{W}\right)$ is located at the southeast of the Bay of Biscay, on the Atlantic coast (Fig. 1). This semi-enclosed lagoon covers a water surface of about $174 \mathrm{~km}^{2}$ at high tide and is characterized by a semi-diurnal mesotidal regime. The tidal amplitude ranges between 0.8 and $4.6 \mathrm{~m}$ for neap and spring tides, respectively. The bay communicates with the Atlantic Ocean through two narrow channels separated by the Arguin sand-bank. Freshwater inputs originate from two main rivers, the Eyre and the Porges Canal, which contribute to more than $95 \%$ of total annual freshwater inflows (Plus et al., 2009), and by several small streams (at the north-eastern and southern parts of the bay). A strong heterogeneity of flushing time occurs inside the bay, causing different confinement levels. Areas close to the ocean are flushed much faster than north-eastern and southern zones (Plus et al., 2009). Indeed, the water located near the lagoon inlets and the river mouths is rapidly renewed (below 1 day), while in others parts of the lagoon, it takes between 12.4 and 17.4 days (Plus et al., 2009). On the basis of the land-sea salinity gradient, three distinct water masses were clearly identified in the bay by Bouchet (1968): (i) external neritic waters, (ii) median neritic waters, (iii) inner neritic waters, shaped proportionally to the distance from the ocean by marine and freshwater inputs. Median waters appear hydrologically closer from external than internal waters, which seem hydrologically isolated (Guillocheau, 1988).

The main ecological habitats characterizing the Arcachon Bay ecosystem are seagrass meadows and Crassostrea gigas reefs. In the inner part of the lagoon $\left(156 \mathrm{~km}^{2}\right)$, the Zostera noltei bed covers an intertidal surface of $70 \mathrm{~km}^{2}$ (Fig. 1). Seagrasses cohabitate with wild oyster reefs whose mean density is estimated at 1000 oysters per $\mathrm{m}^{2}$ (Scourzic et al., 2012; Fig. 1). Primary production is ensured by different contributors: autochthonous macroproducers (mainly Zostera noltei), microphytobenthos on intertidal mudflats and phytoplankton (Dubois et al., 2014). The bay is characterized by low to moderate phytoplankton primary production estimated at $103{\mathrm{~g} \mathrm{C} . \mathrm{m}^{-2}}^{2}$ year $^{-1}$ (Glé et al., 2008). 


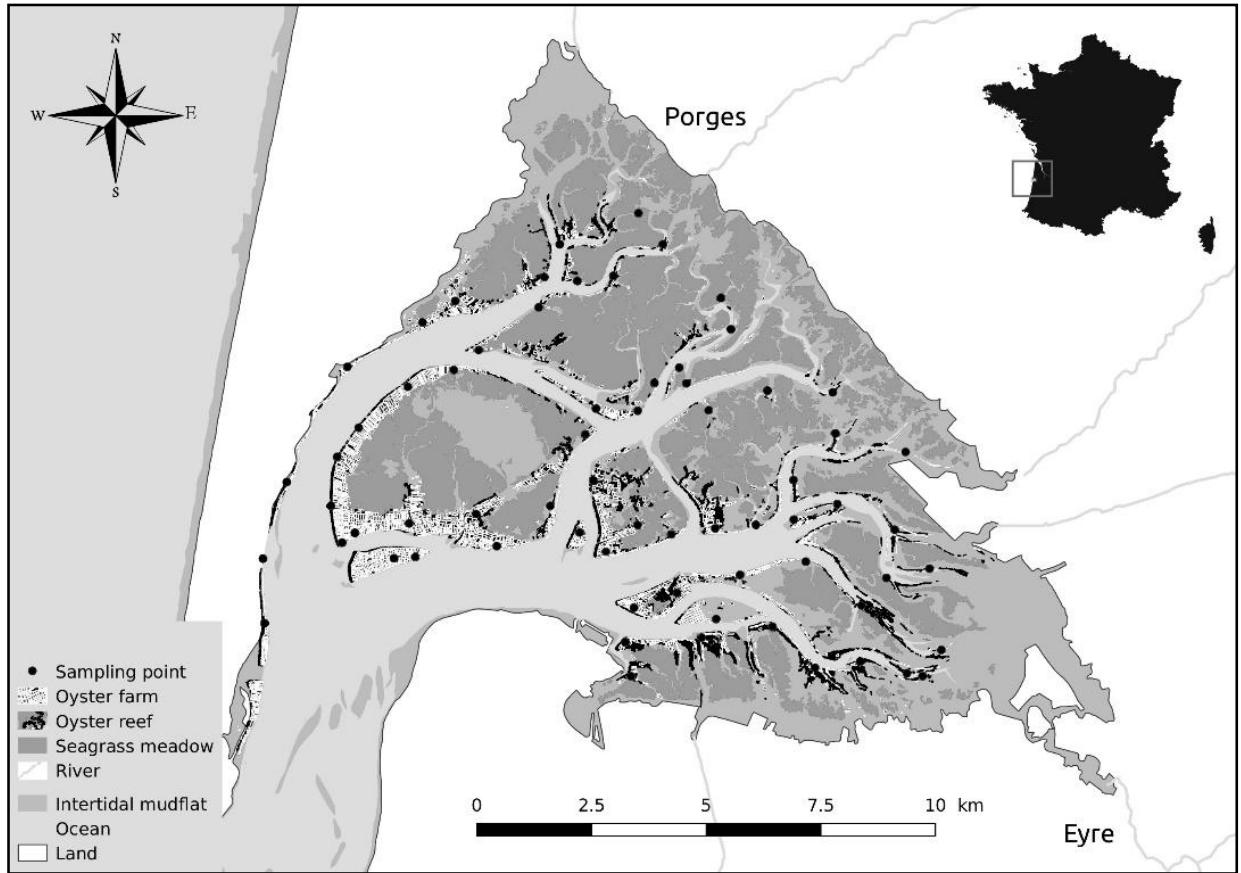

Fig. 1 Map of Arcachon Bay with its principal ecological components: Eyre and Porges rivers; seagrasses beds (Zostera noltei), oyster reefs (Lafond, 2012) and oyster farms.

\subsection{Sampling strategy}

Sampling was carried out on 68 stations of wild oyster reefs in Arcachon Bay according to a stratified random sampling strategy, in June 2013 (Fig. 1). This period was at the end of the seasonal gametogenic cycle and before the release of eggs by oyster genitors in Arcachon Bay (Pouvreau et al., 2016). For each station, 30 adult wild oysters were collected, a minimum whole weight of $18 \mathrm{~g}$ was fixed to prevent juvenile individuals.

\subsection{The somatic-gonadal index}

Biometric analyses were made prior to the calculation of the Lawrence and Scott condition index $\left(\mathrm{LS}_{\mathrm{CI}}\right)$. Although this index is a proxy of the somatic-gonadal volume, the $\mathrm{LS}_{\mathrm{CI}}$ was used here as a proxy of gonadal development, as $C$. gigas gonadal tissues can account for up to $65 \%$ of the total soft body weight in gametogenesis period (Cigarria, 1999; Pouvreau et al., 2006; Ren et al., 2003). $\mathrm{LS}_{\mathrm{CI}}$ is size-independent and thus a good indicator of gonadal volume, independently of oyster age.

The whole weight $(\mathrm{Ww})$ of each oyster was measured after cleaning the shell from epibionts and other debris. Oysters were then opened to separate the flesh from the shell. Soft tissues were 
drained on absorbent paper and wet weighted before being freeze-dried during 48h for dry flesh weight (Dfw) measurements. Shells were weighted (Shw) after being wiped and air dried.

The $\mathrm{LS}_{\mathrm{CI}}$ was calculated for each individual oyster according to the weighing method described by (Lawrence and Scott, 1982) and calculated as follows:

$$
\mathrm{LS}_{\mathrm{CI}}=\frac{\mathrm{Dfw}(\mathrm{g})}{\mathrm{Ww}-\mathrm{Shw}(\mathrm{g})} \times 100
$$

As demonstrated in Lawrence and Scott (1982), the weight of cavity contents (Ww-Shw) is highly correlated to the cavity volume, thus $\mathrm{LS}_{\mathrm{CI}}$ represents the oyster somatic-gonadal volume.

Among the 2040 sampled oysters, 45 oysters showing a biased LS $_{\mathrm{CI}}$ were excluded from the analysis.

\subsection{Tidal processes indices}

\subsubsection{Immersion level $\left(I_{L}\right)$}

Sampling site elevation was used as a proxy of immersion level $\left(\mathrm{I}_{\mathrm{L}}\right)$ and considered as an index of the maximal duration available for oyster feeding. Substrate elevation was extracted for each sampling point from the Lidar bathymetric survey realized by the SIBA (Syndicat Intercommunal du Bassin d'Arcachon) in 2011.

\subsubsection{Local oceanic Flushing time (LoFt)}

The local oceanic flushing time LoFt was used as the time required for a replacement of a significant and localized water fraction by another one coming from the ocean or nearest rivers (Zimmerman, 1976). The LoFt were calculated for the whole bay using the MARS3D numerical model (Lazure and Dumas, 2008) and then extracted for each station. The latest version of the model improved by Kombiadou et al., (2014) from Plus et al., (2009) was used to re-assess the flushing times over the bay. This 3-dimensional version allowed to take into account the hydrodynamic modifications induced by Z. noltei beds.

As our study aimed to examine the relationship between oceanic waters impact on the bay and oyster reproductive performance, the numerical simulation was run without taking into account river discharges in order to remove influences of freshwater inputs in LoFt computation. Because oyster sampling was performed in June 2013, the model was run over the period May-June 2013, 
using realistic seagrass characteristics (in terms of spatial cover and development stage) in order to obtain the most representative LoFt.

\subsection{Data analysis}

\subsubsection{Spatial mapping}

Maps were used in this work to represent spatial patterns of oysters somatic-gonadal index $\mathrm{LS}_{\mathrm{CI}}$. Linear regressions between $\mathrm{LS}_{\mathrm{CI}}$ and geographic coordinates (longitude and latitude) allowed to explore the spatial structure of the data. When significant, the spatial gradient was represented by continuous arrow.

\subsubsection{Statistical modeling}

\section{Linear models}

A first approach was undertaken on the mean oysters somatic-gonadal index $\mathrm{LS}_{\mathrm{CI}}$ values to explore independently the relationships with both proxies of tidal processes $\left(\mathrm{I}_{\mathrm{L}}\right.$ and LoFt). Two linear models were applied according to the following equations:

$$
\begin{gathered}
\text { Linear model }\left(\mathrm{LM}_{1}\right)=\mathrm{LS}_{\mathrm{CI}} \sim \mathrm{I}_{\mathrm{L}}+\varepsilon \\
\text { Linear model }\left(\mathrm{LM}_{2}\right)=\mathrm{LS}_{\mathrm{CI}} \sim \mathrm{LoFt}+\varepsilon
\end{gathered}
$$

where $\mathrm{I}_{\mathrm{L}}$ and LoFt represented the fixed effects and $\varepsilon$ was the "error term" to represent the deviations from the models predictions due to all the random factors that affect $\mathrm{LS}_{\mathrm{CI}}$, independently from $\mathrm{I}_{\mathrm{L}}$ and LoFt.

\section{Mixed models and variance partitioning}

A second approach was undertaken in order to study the $\mathrm{LS}_{\mathrm{CI}}$ response to multiple factors effects. In this part, the total set of $\mathrm{LS}_{\mathrm{CI}}$ data was used to integrate the intra-station variation $\left(\mathrm{IS}_{\mathrm{v}}\right.$ ) into the analysis.

A mixed model incorporating both fixed effect of tidal processes $\mathrm{I}_{\mathrm{L}}$ and LoFt, in addition to a random effect of IS $_{\mathrm{v}}$ was constructed as follows:

$$
\text { Linear mixed model }\left(\mathrm{LMM}_{1}\right)=\mathrm{LS}_{\mathrm{CI}} \sim \mathrm{I}_{\mathrm{L}}+\mathrm{LoFt}+\left(1 \mid \mathrm{IS}_{\mathrm{v}}\right)+\varepsilon
$$

$\left(1 \mid \mathrm{IS}_{\mathrm{v}}\right)$ was applied to precise in the model the use of different random intercepts for each station. 
$\mathrm{I}_{\mathrm{L}}$ and LoFt data were centred and reduced prior to the model application in order to compare their effects on $\mathrm{LS}_{\mathrm{Cl}}$.

The statistical significance of the linear mixed model was verified using the Likelihood Ratio Test. The method was based on the comparison of the full linear mixed model $\left(\mathrm{LMM}_{1}\right)$ against a reduced model incorporating only one fixed effect $\mathrm{I}_{\mathrm{L}}$ or $\operatorname{LoFt}\left(\mathrm{X}, \mathrm{LMM}_{2}\right)$. When anova test revealed a difference between likelihood of this two models, we concluded on the significance of the tested fixed effect $(\mathrm{X})$.

$$
\text { Linear mixed model }\left(\mathrm{LMM}_{2}\right)=\mathrm{LS}_{\mathrm{CI}} \sim \mathrm{X}+\left(1 \mid \mathrm{IS} \mathrm{V}_{\mathrm{V}}\right)+\varepsilon
$$

Finally, a variance partitioning based on multiple linear regression was applied in order to partition the $\mathrm{LS}_{\mathrm{CI}}$ variation into components accounted for the three explanatory variables $\left(\mathrm{I}_{\mathrm{L}}, \mathrm{LoFt}, \mathrm{IS}_{\mathrm{v}}\right)$ and their combined effects.

The tendencies resulted from the linear and linear mixed models were removed to obtain a $\mathrm{LS}_{\mathrm{CI}}$ corrected for fixed $\mathrm{I}_{\mathrm{L}}$, LoFt effects and $\mathrm{IS}_{\mathrm{v}}$ random effect.

All maps and the statistical modeling were elaborated using the R Software (R Development Core Team 2013) and several associated packages (sp, maptools, rgdal, geosphere, SDMTools, Hmisc and RColorBrewer, vegan, lme4). The homoscedasticity and normality of the models residuals were previously verified by examining plots of residuals distribution against fitted values.

\section{Results}

\subsection{Spatial gradient in the somatic-gonadal index of Lawrence and Scott $\left(\operatorname{LS}_{\mathrm{CI}}\right)$}

A significant gradient oriented toward the west-south-west was found in the somatic-gonadal index $\mathrm{LS}_{\mathrm{CI}}$ (Fisher test, $\mathrm{p}$-value < 0.001). The lowest condition indices of Crassostrea gigas were found in the inner part of the bay, while oysters with highest condition indices were found at the vicinity of the mouth of the bay (Fig. 2). At the scale of the whole bay, the average $\mathrm{LS}_{\mathrm{CI}}$ ranged between 4.1 and 11. All southeastern oyster reefs showed weak condition indices ( 39 sites; $\mathrm{LS}_{\mathrm{CI}}$ below 6 ), at the opposite of all southwestern reefs where oysters exhibited the highest condition indices (10 sites; $\mathrm{LS}_{\mathrm{CI}}$ between 9 and 11). 


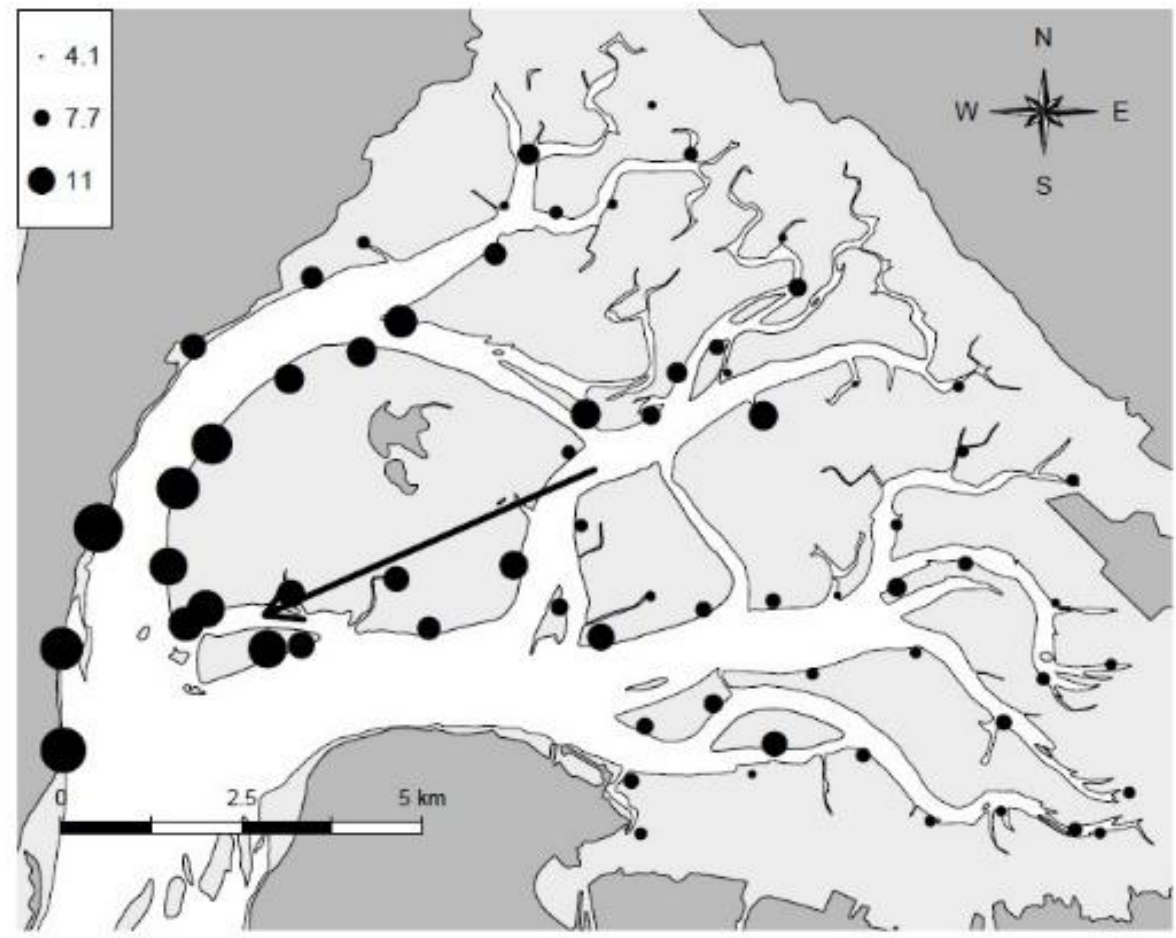

Fig. 2 Spatial pattern of the Lawrence and Scott condition index $\mathrm{LS}_{\mathrm{CI}}$ of the wild Pacific oyster Crassostrea gigas in Arcachon bay. Black arrow indicate a significant gradient at $1 \%$ level $\left(\mathrm{p}=8.16 \mathrm{e}^{-17} ; \mathrm{n}=68\right)$.

\subsection{Spatial variability on tidal processes $I_{L}$ and LoFt}

Both immersion level $\left(\mathrm{I}_{\mathrm{L}}\right)$ and local oceanic flushing time (LoFt) exhibited a spatial heterogeneity. On the 68 stations, highest shore oysters were located at $2.19 \mathrm{~m}$ and lowest shore-level oysters at $0.52 \mathrm{~m}$. For LoFt, the hydrodynamic model revealed high water renewal (low LoFt, below 15 days) near the mouth of the bay and low water renewal (high LoFt, up to 22 days) in the inner parts of the bay (Fig. 3). 


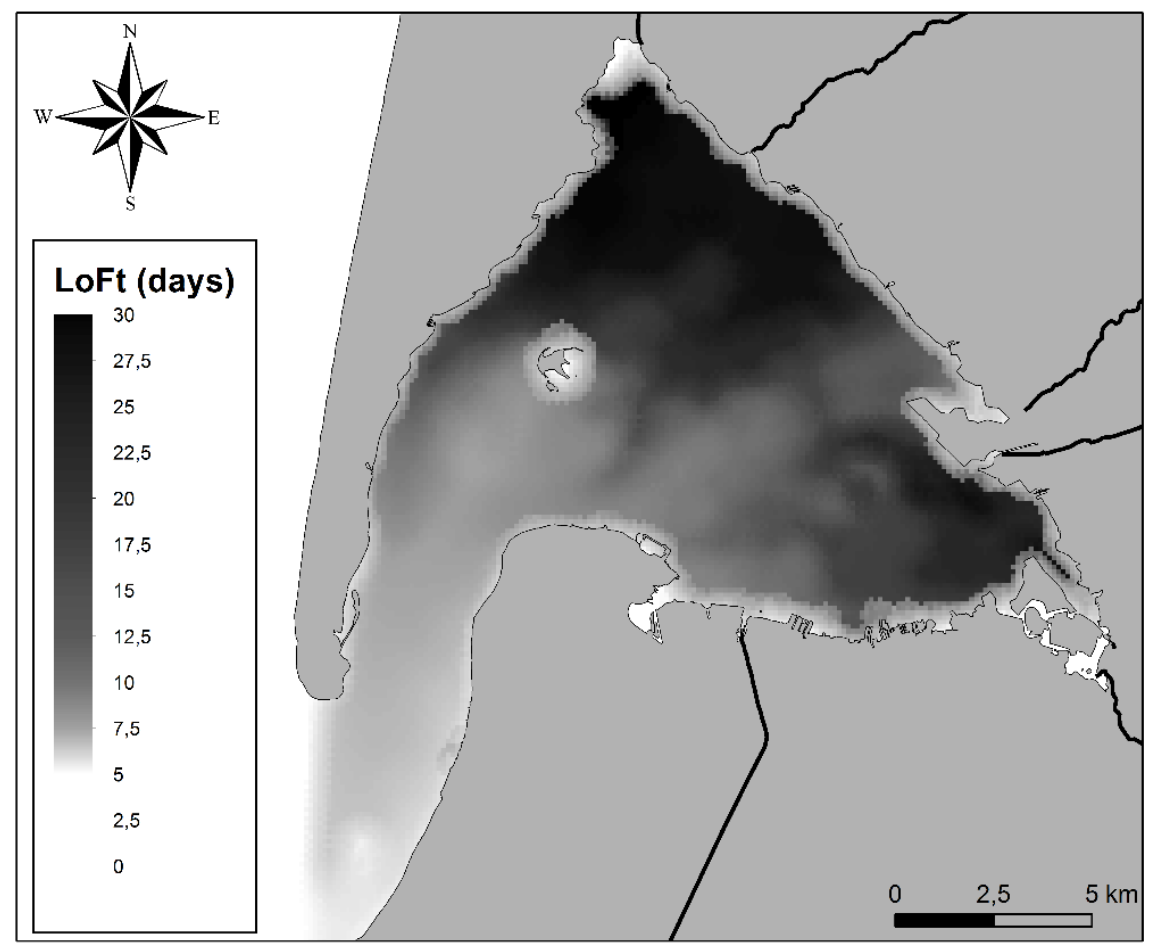

Fig. 3 Local oceanic flushing time (LoFt) calculated over the whole Arcachon Bay using MARS3D numerical model.

\subsection{Tidal processes control on oysters $\mathbf{L S}_{\mathrm{CI}}$}

\section{Linear models}

The two linear models applied on the mean somatic-gonadal index $\mathrm{LS}_{\mathrm{CI}}$ as a function of both immersion time $\mathrm{I}_{\mathrm{L}}$ and local oceanic flushing time LoFt were significant (p-value $<0.001$; Adjusted R-squared=0.33 and 0.5, respectively; Fig. 4).
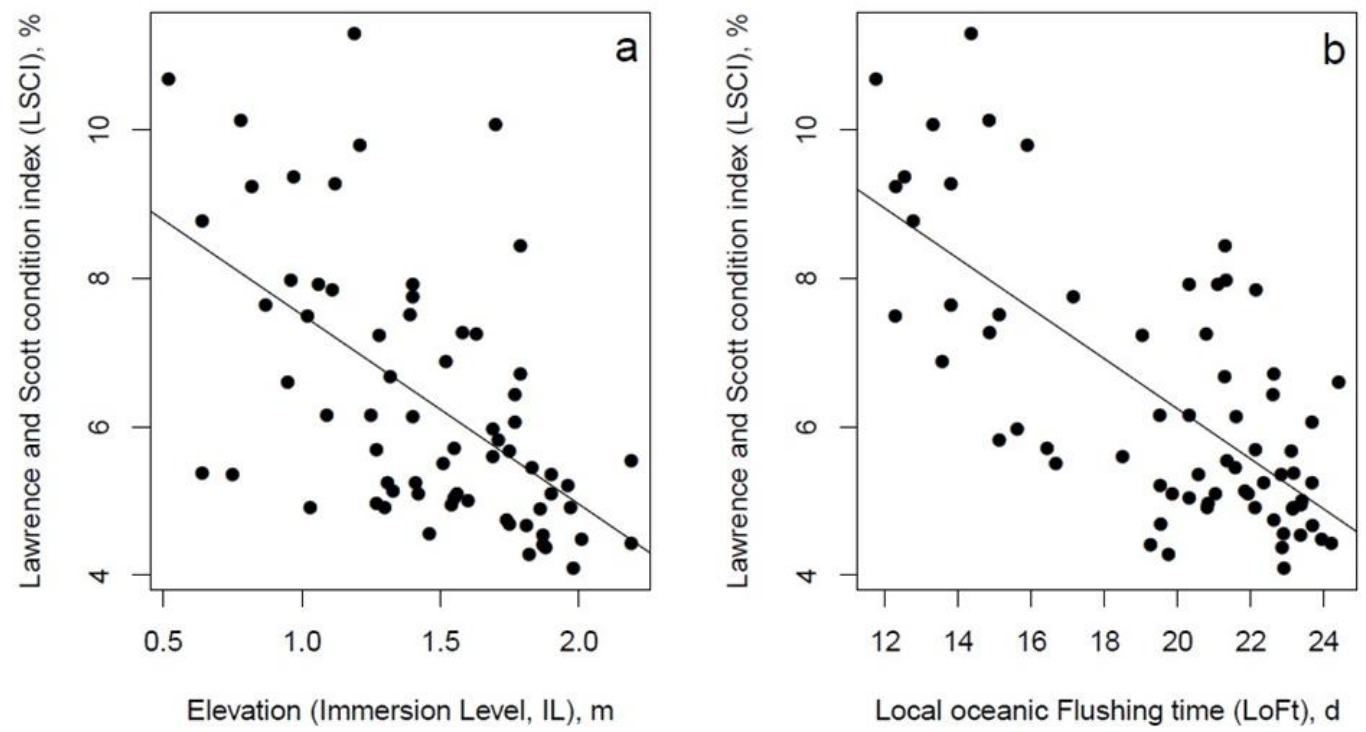

Fig. 4 Linear regressions between Lawrence and Scott condition index $\left(\mathrm{LS}_{\mathrm{CI}}\right)$ of Crassostrea gigas and both tidal process: (a) $\mathrm{LS}_{\mathrm{CI}}$ vs Immersion Level in meter $\left(\mathrm{I}_{\mathrm{L}}\right)$, and (b) $\mathrm{LS}_{\mathrm{CI}}$ vs Local oceanic Flushing time in days ( $\mathrm{LoFt}$ ). The adjusted $\mathrm{R}^{2}$ values were 0.33 and 0.5 respectively. 


\section{Linear mixed models}

The full linear mixed model $\left(\mathrm{LMM}_{1}\right)$ highlighted weak variability for the random effect of the intra-station variation $\mathrm{IS}_{\mathrm{v}}(\mathrm{std} . \mathrm{dev}=1.097)$. For the fixed effects, the Likehood Ratio Test reported the significance of both $\mathrm{I}_{\mathrm{L}}$ and LoFt explanatory variables. $\mathrm{I}_{\mathrm{L}}$ affected $\operatorname{LS}_{\mathrm{CI}}\left(\chi^{2}(1)=14.52\right.$, $\mathrm{p}=0.000138$ ), lowering it by $0.60 \pm 0.15$ (standard errors), while LoFt affected $\operatorname{LS}_{\mathrm{CI}}\left(\chi^{2}(1)=34.82\right.$, $\mathrm{p}=3.61 \mathrm{e}^{-09}$ ), lowering it by $1 \pm 0.15$ (standard errors).

The partitioning of the $\mathrm{LS}_{\mathrm{CI}}$ variability on both tidal processes $\mathrm{I}_{\mathrm{L}}$ and Loft, in addition to the site effect $\mathrm{IS}_{\mathrm{v}}$ allowed to explain $39 \%$ of the global variance, pure effects: $\mathrm{I}_{\mathrm{L}}=3 \% ; \mathrm{LS}_{\mathrm{CI}}=17 \%$ and $\mathrm{IS}_{\mathrm{v}}=4 \%$ and combined effects: $\mathrm{I}_{\mathrm{L}}+\mathrm{Loft}=13 \%$ and $\mathrm{I}_{\mathrm{L}}+\mathrm{IS}_{\mathrm{v}}=2 \%$. Thus, $\mathrm{I}_{\mathrm{L}}$ and $\mathrm{LoFt}$ explained $33 \%$ of $\mathrm{LS}_{\mathrm{CI}}$ variability.

\subsection{Oysters LS $_{C I}$ without $I_{L}$ and LoFt effects}


The relationships described above between the somatic-gonadal index $\mathrm{LS}_{\mathrm{CI}}$ and tidal processes parameters were statistically removed in order to obtain the spatial distribution of $\mathrm{LS}_{\mathrm{CI}}$ corrected for

Lawrence and Scott condition index (LSCI)
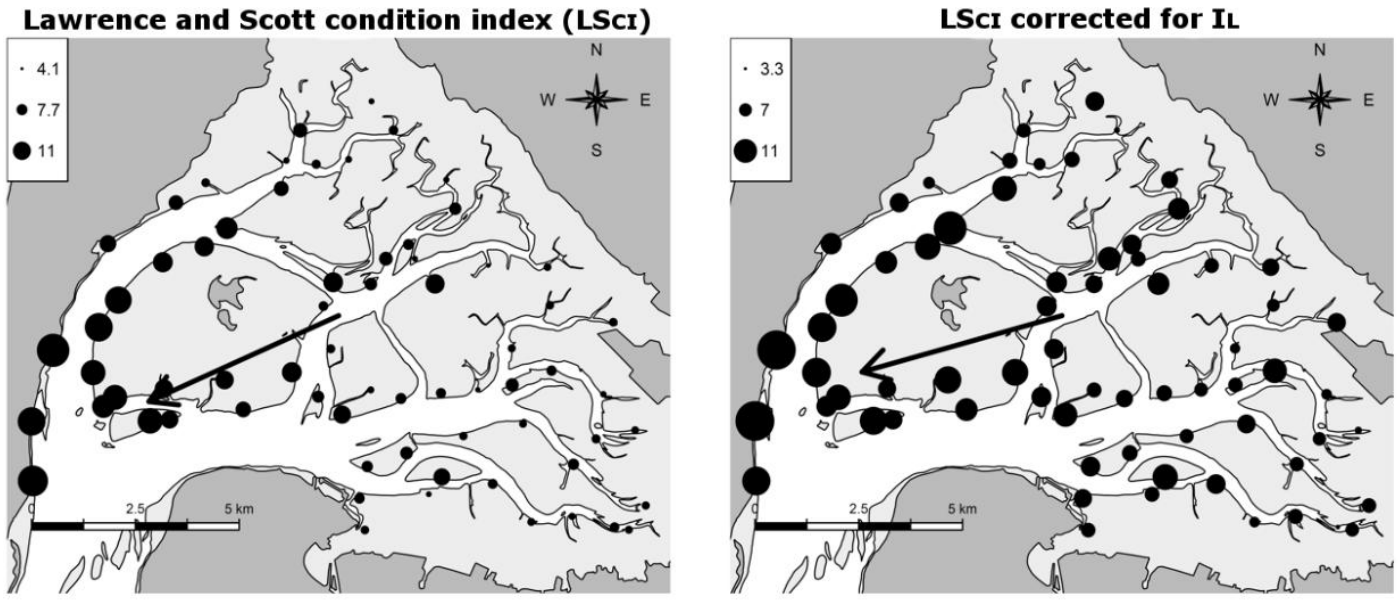

$\mathrm{I}_{\mathrm{L}}$

LScI corrected for LoFt
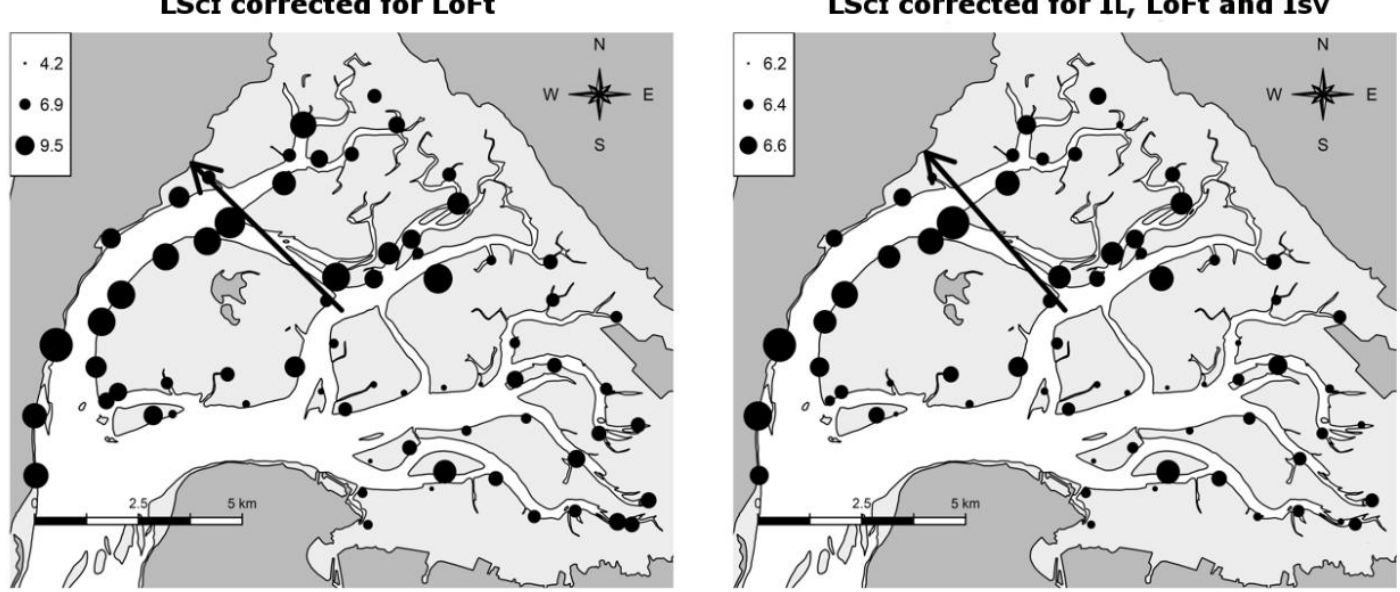

Fig. 5 Spatial pattern of the Lawrence and Scott condition index $\left(\mathrm{LS}_{\mathrm{CI}}\right)$ of the wild Pacific oyster Crassostrea gigas in Arcachon Bay before (a) and after the removing

and of the Immersion level $\left(\mathrm{I}_{\mathrm{L}}, \mathrm{b}\right)$, the Local oceanic Flushing time (LoFt, c) effects and multiple effects of $\mathrm{I}_{\mathrm{L}}$, LoFt and the intra-station variation $\mathrm{I}_{\mathrm{SV}}(\mathrm{d})$. Black arrow indicate a significant residual gradient at $1 \%$ level $\left(b: p=1.6 \mathrm{e}^{-10} ; \mathrm{c}: \mathrm{p}=0.0001 ; \mathrm{d}: \mathrm{p}=\right.$ $\left.9 \mathrm{e}^{-10} ; \mathrm{n}=68\right)$.

$\mathrm{I}_{\mathrm{L}}+\mathrm{LoFt}+\mathrm{IS}_{\mathrm{V}}$ effects. This analysis resulted in a marked change on the direction of $\mathrm{LS}_{\mathrm{CI}}$ residual gradient, revealing a significant gradient of increasing $\mathrm{LS}_{\mathrm{CI}}$ scores from south-east to the north-west (p-value $<0.001$, Fig. 5). 


\section{Discussion}

\subsection{Spatial variability of oyster condition index at regional and local scale}

This work confirmed variability in the condition index of the Pacific oyster Crassostrea gigas along the European Atlantic coast. In comparison with other French oyster culturing sites, such as Brest and Marennes-Oléron Bays, where, in 2013, the Lawrence and Scott condition index LS reached 14.4 and 12.3 respectively, low oyster condition indices were observed in Arcachon Bay (Bernard et al., 2011; Bourlès et al., 2009; Pouvreau et al., 2016). Indeed, Out of the 68 sampled sites, all south-eastern sites showed condition indices below 6 . In general, $\mathrm{LS}_{\mathrm{CI}}$ values above 8 are indicative of oysters in good physiological state (Barillé et al., 2000). In Arcachon bay, this threshold was reached only in south-western sites with a maximum value of 11 . This result is in accordance with the south-north gradient of growth and reproductive output drawn for C. gigas along the west European coast. Wild oyster populations show an increase in gonadal-mass from France to The Netherlands (Cardoso et al., 2007; Enríquez-Díaz et al., 2009). Besides differences in temperature, the most likely explanation of this biological condition of oysters in Arcachon Bay is the low phytoplankton primary productivity (103 $\mathrm{g} \mathrm{C} \mathrm{m}^{-2} \mathrm{y}^{-1}$; Glé et al., 2008). Indeed, C.gigas is known to produce a higher amount of gametes in eutrophic than oligotrophic conditions (Kang et al., 2000). 
At the bay scale, higher condition index in ocean-influenced areas was revealed in contrast with inner-bay areas. The $\mathrm{LS}_{\mathrm{CI}}$ showed a significant gradient in the west-south-west direction. As it has been shown in both Brest Bay and Veys Bays, marine-influenced environment seems to provide better trophic conditions, enhancing $C$. gigas physiological condition (Costil et al., 2005; Royer et al., 2007). Indeed, lower reproductive performance was observed in inner areas, especially around the Eyre River outlet. These findings confirmed the potentially food-depleted conditions of bivalves in south-eastern part of the bay suggested by earlier studies (Caill-Milly et al., 2012; Dang et al., 2010; Robert et al., 1993). Other bivalves such as the Manila clam Ruditapes philippinarum were also revealed to be in poor condition in this area (Caill-Milly et al., 2012; Dang et al., 2010). As oceanic water inputs are apparently beneficial to the development of bivalves (Bacher and Goulletquer, 1989; Robert et al., 1993), relationships between tidal processes and C.gigas reproductive investment might explain the spatial pattern revealed in Arcachon Bay.

\section{2. $\mathrm{LS}_{\mathrm{CI}} v s$. tidal processes}

The significant relationships revealed between $C$. gigas $\mathrm{LS}_{\mathrm{CI}}$ and both proxies of tidal influence did corroborate the positive effect of oceanic influence on the functioning of invertebrate populations in coastal bay. In fact, $33 \%$ of the spatial variability observed on $C$. gigas $\mathrm{LS}_{\mathrm{CI}}$ was explained by pure and combined effects of the immersion level and the local oceanic flushing time $\left(\mathrm{I}_{\mathrm{L}}=3 \%\right.$; LoFt : $\left.17 \% ; \mathrm{LoFt}+\mathrm{I}_{\mathrm{L}}: 13 \%\right)$.

Since $I_{L}$ referred to the bathymetric elevation of the sampled site, it did not exhibit any spatial gradient. Indeed, longer immersion time enhanced the $\mathrm{LS}_{\mathrm{CI}}$ for $C$. gigas because of longer feeding time and lower exposure to biotic interactions and variation in environmental conditions during emersion. Such positive correlation between the quantity of gametes released and the immersion time was previously observed in bivalves (Gillmor, 1982; Goulletquer et al., 1987). A significant increase of oyster somatic-gonadal index when immersed for longer periods was also reported (Goulletquer et al., 1987; Walles et al., 2016). The common mussel Mytilus edulis produces larger eggs when immersion time is longer (Honkoop and van der Meer, 1998).

The positive correlation between $\mathrm{LS}_{\mathrm{CI}}$ and LoFt in the western part may reveal a better feeding environment in the outer part of the bay, potentially due to the rapid and repeated introduction by tide flows of phytoplankton from the Biscay Bay, where the primary production ranges between 145 and $170{\mathrm{~g} \mathrm{C} . \mathrm{m}^{-2} \text { year }}^{-1}$ (Glé et al., 2007; Laborde et al., 1999). Indeed, tidal flushing is one of 
the main bottom-up factors controlling phytoplankton dynamic and biomass in high-shore ecosystems (Glé et al., 2007; Monbet, 1992; Trigueros and Orive, 2000). In the inner part of the bay, longer LoFt limits replenishment of water with oceanic-originating phytoplankton. Oceanic waters reaching the inner part of the bay have already been filtered by outer bay communities, possibly reducing its content in nutritive particles (Herman et al., 1999). In addition, tidal flushing allows organic material resuspension such as microphytobenthos, which has been shown to contribute significantly to $C$. gigas diet in macrotidal estuaries (Marchais et al., 2013; Ubertini et al., 2012). The contrasted reproductive response of $C$. gigas between the outer and the inner bay highlights the ecological isolation of inner water masses. In this area, the trophic potential is mainly controlled by autochthonous primary production and influenced by the seasonal changes of the Eyre River inflows (Castel et al., 1996; Desclaux et al., 2004; Glé et al., 2008; Guillocheau, 1988).

The feeding environment in the river-influenced part of the bay may also have been hampered by a higher competition for food within wild oyster stock. Indeed, for at least a decade, oyster farming areas in the inner bay have been progressively abandoned, which resulted in the development of wild oyster reefs. In 2011, total amount of oyster stocks was estimated in Arcachon Bay to $82500 \mathrm{t}$, with only $16600 \mathrm{t}$ of farmed oysters localized mostly in the outer part of the bay (Fig1, Scourzic et al., 2012). In addition, an interspecific competition may take place in the inner part of the bay, where the biomass of clams, represented mainly by Venerupis philippinarum, was estimated in 2014 at $7138 \mathrm{t}$ (Sanchez et al., 2014). This clam biomass represents a competition for food and may exacerbate the observed gradient in oyster $\mathrm{LS}_{\mathrm{CI}}$ between the outer and the inner part of the bay.

Besides the variability of the trophic environment, several physico-chemical land-sea gradients are enhanced by LoFt or simply correlated with it (i.e. temperature, salinity, turbidity). Their interactions and role on the spatial pattern of food availability and oysters feeding activity must be taken into account in the understanding of the observed pattern of $C$. gigas condition index. South-eastern areas exhibited higher amplitude in temperature, salinity and higher turbidities. Reduced salinity has been observed to negatively affect $C$. gigas growth (Brown and Hartwick, 1988). Moreover, salinity below 30 is known to delay C. gigas gonad development (Muranaka and Lannan, 1984). Even though temperature increases strongly enhance bivalves gamete maturation (Enríquez-Díaz et al., 2009; Fabioux et al., 2005), temperature at $25^{\circ} \mathrm{C}$ decreases oysters filtration 
rate while oxygen consumption increases, affecting feeding activity and energy allocation (Bougrier et al., 1995).

\subsection{Beyond $I_{L}$ and LoFt effects: the residual spatial gradient of $L S_{C I}$}

The reproductive pattern of $C$. gigas is a response to complex interactions and variations in several environmental parameters, mostly modulated in macrotidal ecosystems by tidal processes. It is therefore difficult to disentangle, the effects of each factor on oysters reproductive performance. In this study, a rapid and useful approach had been undertaken to discriminate tidal effects from other independent factors. The effect of both $\mathrm{I}_{\mathrm{L}}$ and LoFt on $\mathrm{LS}_{\mathrm{CI}}$ has been statistically removed and a new spatial pattern was drawn with $\mathrm{LS}_{\mathrm{CI}}$ residual values. Regardless of the elevation level and the distance from ocean, the residual pattern revealed a significant gradient of $\mathrm{LS}_{\mathrm{CI}}$ directed to the north-west. The $61 \%$ of variability in the $\mathrm{LS}_{\mathrm{CI}}$ condition index of $C$. gigas not explained by both tidal processes seem linked to others factors, independent from $\mathrm{I}_{\mathrm{L}}$ and LoFt. Surprisingly, this residual pattern did not oppose inner waters to ocean-influenced waters and takes place in the median bay (Bouchet, 1968). This new gradient suggests that other biological processes or anthropogenic impacts may affect oyster condition. Higher contamination level of HAPs (Polycyclic Aromatic Hydrocarbons) and Copper in C. gigas from the south-eastern bay have been already recorded (Bijoux, 2014; Bernard, unpublished data), especially at the vicinity of the city of Arcachon. The many harbors and anthropic uses, in addition to freshwater inputs from the Eyre River, could represent a source of various pollutants for bivalves. Understanding this residual gradient, and especially the effects of various pollutants on the reproductive ecology of oysters in this area, would be useful for a thorough understanding of Arcachon bay ecological functioning.

\section{Conclusion}

The reproductive performance of wild Pacific oyster Crassostrea gigas was shown to be poor and spatially variable in Arcachon Bay. Important differences in the Lawrence and Scott somatic-gonadal index $\left(\mathrm{LS}_{\mathrm{CI}}\right)$ were recorded between outer and inner bay. The $\mathrm{LS}_{\mathrm{CI}}$ increased significantly along the land-sea gradient and was related to tidal processes. Both immersion level $\left(\mathrm{I}_{\mathrm{L}}\right)$ and oceanic local flushing time $(\mathrm{LoFt})$ explained $33 \%$ from the spatial variability of $\mathrm{LS}_{\mathrm{CI}}$.

Oysters benefitting from high $\mathrm{I}_{\mathrm{L}}$ and rapid and repeated LoFt showed the best biological condition. In the south-eastern areas, oysters appeared affected by the low LoFt and the influence of the Eyre River inputs, reflecting the presence of two hydrographical regions with different characteristics 
and ecological functioning (Marcovecchio et al., 2006). Around the entrance of the bay by the ocean, better trophic environment seems to enhance oyster condition.

This work also allowed to reveal the presence of a second north-west oriented gradient on oysters reproductive performance. Independently from tidal processes, other factors seems to explain the remaining forty-two percent of the $\mathrm{LS}_{\mathrm{CI}}$ variability. The residual gradient once again indicated the low biological state of $C$. gigas in south-eastern part of the bay.

This study suggests that oyster production in the bay could benefit from being displaced to the entrance of the bay, where better growth conditions prevail. In contrast, because larval dispersal to the sea is higher in these areas, spat collection should be performed in the inner bay, where highest retention rates have been observed (Bernard et al., 2014). Indeed, although inner bay oysters had lower physiological condition, they are the main contributors to spat collection in Arcachon Bay. Thus, finding a compromise between good fecundity and low larval dispersion must be considered in the farming practices. The next step to undertake in order to understand the reproductive performance of $C$. gigas in Arcachon Bay would cover the temporal changes in the environmental conditions during the gametogenetic cycle of $C$. gigas, specifically using more specific tools to quantify the trophic potential of the water column in parallel to the physiological response of $C$. gigas.

\section{Acknowledgements}

This study was sponsored by the Syndicat Intercommunal du Bassin d'Arcachon (SIBA), the Comité Régional Conchylicole Arcachon Aquitaine (CRCAA), the Aquitaine Region, the Ministry of Ecology, Sustainable Development and Energy, the European Fisheries Fund (EFF) and the French National Research Agency (ANR) in the frame of the Investments for the future Program, within the Cluster of Excellence COTE (ANR-10-LABEX-45). The scientific coordination was provided by the Institut Français de Recherche pour 1'Exploitation de la Mer (IFREMER). We thank Tugdual Drean and Julie Duchêne for their participation to the fieldwork, Stéphane Bujan for the DGPRS measures and the Laboratoire Environnement Ressources d'Arcachon (PDG-ODE-LITTORAL-LERAR) for the technical and logistical support.

\section{References}

Alunno-Bruscia, M., Bourlès, Y., Maurer, D., Robert, S., Mazurié, J., Gangnery, A., Goulletquer, P., Pouvreau, S., 2011. A single bio-energetics growth and reproduction model for the oyster Crassostrea gigas in six Atlantic ecosystems. J. Sea Res. 66, 340-348. doi:10.1016/j.seares.2011.07.008.

Auby, I., Maurer, D., Passoni, S., Heroin, D., Rigouin, L., Meteigner, C., Perriere Rumebe, M., 
Tournaire, M.P., Simonnet, B., Navarro, R., 2014. Reproduction de l'huître creuse dans le Bassin d'Arcachon. Ifremer 55. doi:10.13155/35451.

Bacher, C., Goulletquer, P., 1989. Comparaison des relations trophiques de Ruditapes philippinarum en milieux extuarien et océanique à partir d'un modèle de croissance. Can. J. Fish. Aquat. Sci. 46, 1160-1170.

Barillé, L., Haure, J., Cognie, B., Leroy, A., 2000. Variations in pallial organs and eulatero-frontal cirri in response to high particulate matter concentrations in the oyster Crassostrea gigas. Can. J. Fish. Aquat. Sci. 57, 837-843. doi:10.1139/cjfas-57-4-837.

Bernard, I., 2011. Écologie de la reproduction de l'huître creuse, Crassostrea gigas, sur les côtes atlantiques françaises: Vers une explication de la variabilité du captage. $\mathrm{PhD}$ Thesis, Université de La Rochelle.

Bernard, I., Allain, G., Auby, I., Plus, M., Drean, T., Gasmi, S., David, V., Pouvreau, S., Maurer, D., 2014. Étude de la fécondité de l'huître creuse dans le bassin d'Arcachon en 2013 en lien avec la qualité de l'eau. Rapport final du projet FeLiBA. CRCAA, p 60.

Bernard, I., De Kermoysan, G., Pouvreau, S., 2011. Effect of phytoplankton and temperature on the reproduction of the Pacific oyster Crassostrea gigas: Investigation through DEB theory. J. Sea Res. 66, 349-360. doi:10.1016/j.seares.2011.07.009.

Berthelin, C., Kellner, K., Mathieu, M., 2000. Storage metabolism in the Pacific oyster (Crassostrea gigas) in relation to summer mortalities and reproductive cycle (West Coast of France). Comp. Biochem. Physiol. B. Biochem. Mol. Biol. 125, 359-369. doi:10.1016/S0305-0491(99)00187-X.

Bijoux, H., 2014. Etude des impacts toxiques des contaminants chimiques du Bassin d'Arcachon sur l'huitre cultivée Crassostrea gigas: Approche in-situ et expérimentale. PhD Thesis, Université de Bordeaux.

Bouchet, J.-M., 1968. Etude océanographique des chenaux du Bassin d'Arcachon. PhD Thesis, Université de Bordeaux.

Bougrier, S., Geairon, P., Deslous-Paoli, J.M., Bacher, C., Jonquières, G., 1995. Allometric relationships and effects of temperature on clearance and consumption rates of Crassostrea gigas (Thunberg). Aquaculture 134, 143-154. 10. doi:1016/0044-8486(95)00036-2

Bourlès, Y., Maurer, D., Moine, O. Le, Geairon, P., Mazurié, J., Gangnery, A., Pouvreau, S., 2009. Modelling growth and reproduction of Crassostrea gigas in different contrasted ecosystems by use of Dynamic Energy Budgets ( DEB ): generic validation of the oyster-DEB model. Group 10-10. doi:10.1016/j.seares.2009.03.002.

Brown, J.R., Hartwick, E.B., 1988. Influences of temperature, salinity and available food upon suspended culture of the Pacific oyster, Crassostrea gigas. I. Absolute and allometric growth. Aquaculture 70, 231-251. doi:10.1016/0044-8486(88)90099-3.

Caill-Milly, N., Bru, N., Mahé, K., Borie, C., D’Amico, F., 2012. Shell Shape Analysis and Spatial Allometry Patterns of Manila Clam (Ruditapes philippinarum) in a Mesotidal Coastal Lagoon. 
J. Mar. Biol. 2012, 1-11. doi:10.1155/2012/281206.

Cardoso, J.F.M.F., Langlet, D., Loff, J.F., Martins, A.R., Witte, J.I., Santos, P.T., Van Der Veer, H.W., 2007. Spatial variability in growth and reproduction of the Pacific oyster Crassostrea gigas (Thunberg, 1793) along the west European coast. J. Sea Res. 57, 303-315. doi:10.1016/j.seares.2006.11.003.

Castel, J., Caumettel, P., Herbert, R., 1996. Eutrophication gradients in coastal lagoons as exemplified by the Bassin d'Arcachon and the Etang du Prevost. Hydrobiologia 329. doi:10.1007/BF00034542.

Chávez-Villalba, J., Barret, J., Mingant, C., Cochard, J.C., Le Pennec, M., 2002a. Autumn conditioning of the oyster Crassostrea gigas: A new approach. Aquaculture 210, 171-186. doi:10.1016/S0044-8486(02)00059-5.

Chávez-Villalba, J., Pommier, J., Andriamiseza, J., Pouvreau, S., Barret, J., Cochard, J.C., Le Pennec, M., 2002b. Broodstock conditioning of the oyster Crassostrea gigas: Origin and temperature effect. Aquaculture 214, 115-130. doi:10.1016/S0044-8486(01)00898-5.

Cigarria, J., 1999. Effects of age, size, and season on growth of soft tissue in the oyster Crassostrea gigas (Thunberg, 1793). J. Shellfish Res. 18, 127-131.

Cloern, J.E., Powell, T.M., Huzzey, L.M., 1989. Spatial and temporal variability in South San Francisco Bay (USA). II. Temporal changes in salinity, suspended sediments, and phytoplankton biomass and productivity over tidal time scales. Estuar. Coast. Shelf Sci. 28, 599-613. doi:10.1016/0272-7714(89)90049-8.

Cognie, B., Haure, J., Barillé, L., 2006. Spatial distribution in a temperate coastal ecosystem of the wild stock of the farmed oyster Crassostrea gigas (Thunberg). Aquaculture 259, 249-259. doi:10.1016/j.aquaculture.2006.05.037.

Costil, K., Royer, J., Ropert, M., Soletchnik, P., Mathieu, M., 2005. Spatio-temporal variations in biological performances and summer mortality of the Pacific oyster Crassostrea gigas in Normandy (France). Helgol. Mar. Res. 59, 286-300. doi:10.1007/s10152-005-0004-5.

Dang, C., De Montaudouin, X., Gam, M., Paroissin, C., Bru, N., Caill-Milly, N., 2010. The Manila clam population in Arcachon Bay (SW France): Can it be kept sustainable? J. Sea Res. 63, 108-118. doi:10.1016/j.seares.2009.11.003.

De Wit, R., Stal, L.J., Lomstein, B.A., Herbert, R. A., Van Gemerden, H., Viaroli, P., Cecherelli, V.U., Rodríguez-Valera, F., Bartoli, M., Giordani, G., Azzoni, R., Schaub, B., Welsh, D.T., Donnelly, A., Cifuentes, A., Antón, J., Finster, K., Nielsen, L.B., Pedersen, A.G.U., Neubauer, A.T., Colangelo, M. a., Heijs, S.K., Ceccherelli, V.U., Rodriguez-Valera, F., Bartoli, M., Giordani, G., Azzoni, R., Schaub, B., Welsh, D.T., Donnelly, A., Cifuentes, A., Antòn, J., Finster, K., Nielsen, L.B., Underlien Pedersen, A.-G., Turi Neubauer, A., Colangelo, M. a., Heijs, S.K., 2001. ROBUST: The ROle of BUffering capacities in STabilising coastal lagoon ecosystems. Cont. Shelf Res. 21, 2021-2041. doi:10.1016/S0278-4343(01)00040-1.

Desclaux, C., De Montaudouin, X., Bachelet, G., 2004. Cockle Cerastoderma edule population mortality: Role of the digenean parasite Himasthla quissentensis. Mar. Ecol. Prog. Ser. 279, 
141-150. doi:10.3354/meps279141.

Dridi, S., Romdhane, M.S., Elcafsi, M., 2007. Seasonal variation in weight and biochemical composition of the Pacific oyster, Crassostrea gigas in relation to the gametogenic cycle and environmental conditions of the Bizert lagoon, Tunisia. Aquaculture 263, 238-248. doi:10.1016/j.aquaculture.2006.10.028.

Dubois, S., Blanchet, H., Garcia, A., Massé, M., Galois, R., Grémare, A., Charlier, K., Guillou, G., Richard, P., Savoye, N., 2014. Trophic resource use by macrozoobenthic primary consumers within a semi-enclosed coastal ecosystem: Stable isotope and fatty acid assessment. J. Sea Res. 88, 87-99. doi:10.1016/j.seares.2014.01.004.

Dutertre, M., Beninger, P.G., Barillé, L., Papin, M., Haure, J., 2010. Rising water temperatures, reproduction and recruitment of an invasive oyster, Crassostrea gigas, on the French Atlantic coast. Mar. Environ. Res. 69, 1-9. doi:10.1016/j.marenvres.2009.07.002.

Dutertre, M., Beninger, P.G., Barillé, L., Papin, M., Rosa, P., Barillé, A.L., Haure, J., 2009. Temperature and seston quantity and quality effects on field reproduction of farmed oysters, Crassostrea gigas, in Bourgneuf Bay, France. Aquat. Living Resour. 22, 319-329. doi:10.1051/alr/2009042.

Enríquez-Díaz, M., Pouvreau, S., Chávez-Villalba, J., Le Pennec, M., 2009. Gametogenesis, reproductive investment, and spawning behavior of the Pacific giant oyster Crassostrea gigas: Evidence of an environment-dependent strategy. Aquac. Int. 17, 491-506. doi:10.1007/s10499-008-9219-1.

Fabioux, C., Huvet, A., Le Souchu, P., Le Pennec, M., Pouvreau, S., 2005. Temperature and photoperiod drive Crassostrea gigas reproductive internal clock. Aquaculture 250, 458-470. doi:10.1016/j.aquaculture.2005.02.038.

Gillmor, R.B., 1982. Assessment of intertidal growth and capacity adaptations in suspension-feeding bivalves. Mar. Biol. 68, 277-286. doi:10.1007/BF00409594.

Glé, C., Del Amo, Y., Bec, B., Sautour, B., Froidefond, J.M., Gohin, F., Maurer, D., Plus, M., Laborde, P., Chardy, P., 2007. Typology of environmental conditions at the onset of winter phytoplankton blooms in a shallow macrotidal coastal ecosystem, Arcachon Bay (France). J. Plankton Res. 29, 999-1014. doi:10.1093/plankt/fbm074.

Glé, C., Del Amo, Y., Sautour, B., Laborde, P., Chardy, P., 2008. Variability of nutrients and phytoplankton primary production in a shallow macrotidal coastal ecosystem (Arcachon Bay, France). Estuar. Coast. Shelf Sci. 76, 642-656. doi:10.1016/j.ecss.2007.07.043.

Goulletquer, P., Lombas, I., Prou, J., 1987. Influence du temps d'immersion sur l'activité reproductrice et sur la croissance de la palourde japonaise Ruditapes philippinarum et l'huître japonaise Crassostrea gigas. Haliotis 16, 453-462.

Grangeré, K., Lefebvre, S., Blin, J.L., 2012. Spatial and temporal dynamics of biotic and abiotic features of temperate coastal ecosystems as revealed by a combination of ecological indicators. Estuar. Coast. Shelf Sci. 108, 109-118. doi:10.1016/j.ecss.2012.02.020. 
Grant, J., 1996. The relationship of bioenergetics and the environment to the field growth of cultured bivalves. J. Exp. Mar. Bio. Ecol. 200, 239-256. doi:10.1016/S0022-0981(96)02660-3.

Guillocheau, N., 1988. Répartition spatio-temporelle du phytoplancton du bassin d'Arcachon. PhD Thesis, Université d'Aix-Marseille II.

Herman, P.M.J., Middelburg, J.J., Van De Koppel, J., Heip, C.H.R., 1999. Ecology of Estuarine Macrobenthos, Advances in Ecological Research. doi:10.1016/S0065-2504(08)60194-4.

Honkoop, P.J.., Van Der Meer, J., 1998. Experimentally induced effects of water temperature and immersion time on reproductive output of bivalves in the Wadden Sea. J. Exp. Mar. Bio. Ecol. 220, 227-246. doi:10.1016/S0022-0981(97)00107-X.

Kang, C.K., Park, M.S., Lee, P.Y., Choi, W.J., Lee, W.C., 2000. Seasonal variations in condition, reproductive activity, and biochemical composition of the Pacific oyster, Crassostrea gigas (Thunberg), in suspended culture in two coastal bays of Korea. J. Shellfish Res. 19, 771-778.

Kombiadou, K., Ganthy, F., Verney, R., Plus, M., Sottolichio, A., 2014. Modelling the effects of Zostera noltei meadows on sediment dynamics: application to the Arcachon lagoon. Ocean Dyn. 64, 1499-1516. doi:10.1007/s10236-014-0754-1.

Laborde, P., Urrutia, J., Valencia, V., 1999. Seasonal variability of primary production in the Cap-Ferret Canyon area (Bay of Biscay) during the ECOFER cruises. Deep. Res. Part II Top. Stud. Oceanogr. 46, 2057-2079. doi:10.1016/S0967-0645(99)00055-7.

Lafond, V., 2012. Cartographie de la limite inférieure du shorre, des champs d'huîtres et des lacs de tonne par télédétection. Agence des Aires Marines Protégées CREOCEAN, p 52.

Lango-Reynoso, F., Chávez-Villalba, J., Cochard, J.C., Le Pennec, M., 2000. Oocyte size, a means to evaluate the gametogenetic development of the Pacific oyster, Crassostrea gigas (Thunberg). Aquaculture 190, 183-199. doi:10.1016/S0044-8486(00)00392-6.

Lango-Reynoso, F., Devauchelle, N., Le Pennec, M., Hatt, P.J., 1999. Elements of reproductive strategy in oysters, Crassostrea gigas, from the "Rade de Brest", France. Invertebr. Reprod. Dev. 36, 141-144. doi:10.1080/07924259.1999.9652690.

Lawrence, D.R., Scott, G.I., 1982. The determination and use of condition index of oysters. Estuaries 5, 23-27. doi:10.1007/BF02803952.

Lazure, P., Dumas, F., 2008. An external-internal mode coupling for a 3D hydrodynamical model for applications at regional scale (MARS). Adv. Water Resour. doi:10.1016/j.advwatres.2007.06.010.

Leal, M.J.C., Dubois, S., Orvain, F., Galois, R., Blin, J.L., Ropert, M., Bataillé, M.P., Ourry, A., Lefebvre, S., 2008. Stable isotopes $\left(\delta^{13} \mathrm{C}, \delta^{15} \mathrm{~N}\right)$ and modelling as tools to estimate the trophic ecology of cultivated oysters in two contrasting environments. Mar. Biol. 153, 673-688. doi:10.1007/s00227-007-0841-7.

Mallin, M.A., Paerl, H.W., Rudek, J., Bates, P.W., 1993. Regulation of estuarine primary 
production by watershed rainfall and river flow. Mar. Ecol. Prog. Ser. 93, 199-203. doi:10.3354/meps093199.

Marchais, V., Schaal, G., Grall, J., Lorrain, A., Nerot, C., Richard, P., Chauvaud, L., 2013. Spatial Variability of Stable Isotope Ratios in Oysters (Crassostrea gigas) and Primary Producers Along an Estuarine Gradient (Bay of Brest, France). Estuaries and Coasts 36, 808-819. doi:10.1007/s12237-012-9584-x.

Marcovecchio, J., Freije, H., De Marco, S., Gavio, A., Ferrer, L., Andrade, S., Beltrame, O., Asteasuain, R., 2006. Seasonality of hydrographic variables in a coastal lagoon: Mar Chiquita, Argentina. Aquat. Conserv. Mar. Freshw. Ecosyst. 16, 335-347. doi:10.1002/aqc.719.

Martin, J.L., Haure, J., Dupuy, B., Nourry, M., Palvadeau, H., Papin, M., Penisson, C., Thouard, E., 2005. Estimation des stocks d'huîtres sauvages sur les zones non concédées de la partie vendéenne de la Baie de Bourgneuf en 2004. Rapport Ifremer AGS/LGP/Bouin/2005-01, p 21.

Monbet, Y., 1992. Control of Phytoplankton Biomass in Estuaries: A Comparative Analysis of Microtidal and Macrotidal Estuaries. Estuaries 15, 563. doi:10.2307/1352398.

Muranaka, M.S., Lannan, J.E., 1984. Broodstock management of Crassostrea gigas: Environmental influences on broodstock conditioning. Aquaculture 39, 217-228. doi:10.1016/0044-8486(84)90267-9.

Newell, R.I.. R., 2004. Ecosystem influences of natural and cultivated populations of suspension-feeding bivalve molluscs: a review. J. Shellfish Res. doi:10.2983/035.029.0302.

Plus, M., Dumas, F., Stanisière, J.Y., Maurer, D., 2009. Hydrodynamic characterization of the Arcachon Bay, using model-derived descriptors. Cont. Shelf Res. doi:10.1016/j.csr.2008.12.016.

Pouvreau, S., Petton, S., Huber, M., Le Roy, V., Queau, I., Le Souchu, P., Alunno-Bruscia, M., Boudry, P., Palvadeau H., Auby, I., Maurer, D., D'Amico, F., Passoni S., Barbier, C., Tournaire, MP., Rigouin, L., Rumebe, M., Fleury, E., Bellec, G., Bouget, JP., Pepin, JF., Roque D'Orbcastel, E., Quemener, L., Repecaud, M., Mille, D., Geay, A., Bouquet, AL., 2016. Observer, Analyser et Gérer la variabilité de la reproduction et du recrutement de l'huître creuse en France: Le Réseau Velyger, Rapport annuel 2015. Rapport Ifremer, RBE/PFOM/PI 2016-1, p 57.

Pouvreau, S., Rambeau, M., Cochard, J.C., Robert, R., 2006. Investigation of marine bivalve morphology by in vivo MR imaging: First anatomical results of a promising technique. Aquaculture 259, 415-423. doi:10.1016/j.aquaculture.2006.05.018.

Powell, T.M., Cloern, J.E., Huzzey, L.M., 1989. Spatial and temporal variability in South San Francisco Bay (USA). I. Horizontal distributions of salinity, suspended sediments, and phytoplankton biomass and productivity. Estuar. Coast. Shelf Sci. 28, 583-597. doi:10.1016/0272-7714(89)90048-6.

Prins, T.C., Smaal, A.C., Dame, R.F., 1997. A review of the feedbacks between bivalve grazing and ecosystem processes. Aquat. Ecol. 31, 349-359. doi:10.1023/A:1009924624259. 
Quantum, G.I.S., 2015. Development Team. Quantum GIS geographic information system. Open source geospatial foundation project. Free Softw. Found. India.

Ren, J.S., Marsden, I.D., Ross, A.H., Schiel, D.R., 2003. Seasonal variation in the reproductive activity and biochemical composition of the Pacific oyster (Crassostrea gigas) from the Marlborough Sounds, New Zealand. New Zeal. J. Mar. Freshw. Res. 37, 171-182. doi:10.1080/00288330.2003.9517155.

Riera, P., Richard, P., 1996. Isotopic determination of food sources of Crassostrea gigas along a trophic gradient in the estuarine Bay of Marennes-Oléron. Estuar. Coast. Shelf Sci. 42, 347-360. doi:10.1006/ecss.1996.0023.

Robert, R., Trut, G., Laborde, J.L., 1993. Growth, reproduction and gross biochemical composition of the Manila clam Ruditapes philippinarum in the Bay of Arcachon, France. Mar. Biol. 116, 291-299. doi: 10.1007/BF00350019.

Roegner, G.C., 1998. Hydrodynamic control of the supply of suspended chlorophyll a to infaunal estuarine bivalves. Estuar. Coast. Shelf Sci. 47, 369-384. doi:10.1006/ecss.1998.0351.

Roegner, G.C., Shanks, A.L., 2001. Import of Coastally-Derived Chlorophyll a to South Slough, Oregon. Estuaries 24, 244. doi:10.2307/1352948.

Royer, J., Ropert, M., Costil, K., 2007. Spatio-temporal changes in mortality, growth and condition of the Pacific oyster, Crassostrea gigas, in Normandy (France). J. Shellfish Res. 26, 973-984.

Sanchez, F., Caill-Milly, N., Lissardy, M., Bru, N., 2014. Campagne d'évaluation de stock de palourdes du bassin d'Arcachon Année 2014. Rapport Ifremer RBE/HGS/LRHA 14-003, p 53.

Scourzic, T., Loyen, M., Fabre, E., Tessier, A., Dalias, N., Trut, G., Maurer, D., Simmonnet, B., 2012. Estimation du stock d'huîtres sauvages et en élevage dans le Bassin d'Arcachon. Rapport Ifremer, OCEANIDE, AAMP, p 69.

Soletchnik, P., Geairon, P., Le Moine, O., Robert, S., 2012. Estimation des stocks sauvages d'huîtres creuses dans les pertuis charentais en 2010. Rapport Ifremer. ODE/LER/LERPC, $p$ 33.

Team, R.D.C., 2013. A language and environment for statistical computing. R Foundation for Statistical Computing, Vienna, Austria.

Trigueros, J.M., Orive, E., 2000. Tidally driven distribution of phytoplankton blooms in a shallow, macrotidal estuary. J. Plankton Res. 22, 969-986. doi:10.1093/plankt/22.5.969.

Ubertini, M., Lefebvre, S., Gangnery, A., Grangeré, K., Le Gendre, R., Orvain, F., 2012. Spatial Variability of Benthic-Pelagic Coupling in an Estuary Ecosystem: Consequences for Microphytobenthos Resuspension Phenomenon. PLoS One 7. doi:10.1371/journal.pone.0044155.

Walles, B., Troost, K., Van Den Ende, D., Nieuwhof, S., Smaal, A.C., Ysebaert, T., 2016. From 
artificial structures to self-sustaining oyster reefs. J. Sea Res. 108, 1-9. doi:10.1016/j.seares.2015.11.007.

Zimmerman, J.T.F., 1976. Mixing and flushing of tidal embayments in the western Dutch Wadden Sea part I: Distribution of salinity and calculation of mixing time scales. Netherlands J. Sea Res. 10, 149-191. doi:10.1016/0077-7579(76)90013-2. 


\section{Research highlights}

$>$ The somatic-gonadal index of the wild Pacific oyster Crassostrea gigas was higher in ocean-influenced areas than in river-influenced areas

$>33 \%$ of the Lawrence and Scott condition index ( $\mathrm{LSCI})$ variability was explained by two tidal processes: immersion level (IL) and local oceanic flushing time (LoFt)

$>$ Longer immersion time and organic matter inputs from the ocean enhance $C$. gigas gonadal development 